\title{
Global positioning system based spatial and temporal distribution of new leaf curl begomovirus disease on sunflower in Northern Karnataka
}

\author{
M. Vindyashree ${ }^{1}$, M.R. Govindappa ${ }^{*}$, D.S. Aswathanarayana ${ }^{1}$, V.N. Ghante ${ }^{2}$, M.B. Patil ${ }^{1}$ \\ and I. Shankergoud ${ }^{2}$ \\ ${ }^{1}$ Department of Plant Pathology, University Of Agricultural Sciences, Raichur- 584104 (Karnataka) INDIA \\ ${ }^{2}$ AICRP on Sunflower, MARS, University Of Agricultural Sciences, Raichur- 584104 (Karnataka ) INDIA \\ "Corresponding author. E-mail: mrgpathology1@gmail.com
}

Received: July 20, 2015; Revised received: March 20, 2016; Accepted: June 4, 2016

\begin{abstract}
Leaf curl disease on sunflower caused by begomovirus genus of the family geminiviridae. Present investigations on field survey for disease incidence, field diagnostic symptoms and its spatial and temporal distribution in major sunflower growing parts of North Eastern Karnataka through GPS system during 2013-14, revealed that the disease was found to occur at all the stages of sunflower under field condition and exhibited symptoms such as vein thickening (enations) on abaxial surface of the leaves, upward curling and reduction in leaf size and severe discoluration of capitulum (Head) followed by bushy appearance. GPS based survey indicated that the \% disease incidence varied from location to location (spatial variation) and also from season to season (temporal variation). The low incidence was noticed during Kharif condition which is ranged between 6.34-11.16, with the average incidence of $11.2 \%, 7.4 \%$ and $6.3 \%$ in Koppal, Raichur and Ballari districts repectively. Whereas during Rabi/ summer season, high magnitude of disease noticed in many of the locations surveyed and is recorded upto $92.9 \%$. The GPS maps plotted based on PDI scale (0-3) represents high risk areas of the disease in Raichur and adjacent areas of Nort Eastern Karnataka and the result shows that the disease occurrence was more in rabi as compared to Kharif situations irrespective of locations. GPS survey map is an indicator to locate the nature of disease spread so as to conclude the hotspot areas.
\end{abstract}

Keywords: Begomovirus, GPS survey, Leaf curl disease, Sunflower, Whitefly

\section{INTRODUCTION}

Sunflower one of the important edible oilseed crop grown in the world after soybean and groundnut. The oil is also a rich source (64\%) of lenoleic acid which helps in washing out cholesterol deposition in the coronary arteries. Sunflower has gained importance due to its short duration of maturity, excellent quality oil, photo-insensitivity, wide adaptability in different agroclimatic region and drought tolerance (Joshi, 2009; Mündel, 2009).

Although the area under cultivation increased with the adventure of new hybrids and varieties by private and public sectors, the crop being suffer from many fungal and viral diseases (Saharan et al., 2005). Among viral diseases affecting sunflower, very recently leaf curl disease caused by begomovirus of the geminiviridae family was reported for the first time from Main Agricultural Research Station (MARS), University of Agricultural Sciences (UAS) campus, Raichur. Causal agent of the disease was confirmed as ss DNA begomovirus which is clustered next to Tomato Leaf Curl Karnataka Virus isolate Lucknow (ToLCKV-[Luc] (Accession no. EU604297.2). and Tomato Leaf Curl Virus - Bangalore II (ToLCBV-[Ban2]) (Accession no.
EU604297.2) and shared 97.5\% nucleotide identities (Govindappa et al., 2011).

The emergence of the whitefly transmitted geminivirus complex around the world depends on various factors, such as exchange of genetic information by recombination plays a role in the evolution of viruses, evolution of variants of the viruses, changes in the biology of vectors, movement of infected planting materials, introduction of new crops and host susceptibility genes through the exchange of germplasm, changes in cropping systems, and climatic factors (Muniyappa and Veeresh, 1984, Saikia and Muniyappa, 1989, Brown, 1994, Ramappa et al., 1998, Banks et al., 2001, Varma and Malathi, 2003., Shivalingama et al., 2007; Kaur et al., 2015).

Although leaf curl disease noticed on sunflower for the first time on sunflower hybrid SB-275 grown in research experimental plots at MARS, Raichur, the incidence level increasing year after year. Further during Kharif 2012, highest incidence (72\%) was noticed in many sunflower pipeline hybrids viz., KSFH-335, KBSH-70, KSFH-280, KBSH-68, KBSH-1, KBSH-44, KSFH-284, NSSH-1084, DOLLER, NSFH-1001, VSFH-204, SB-275, Morden and BSFH-111 with the incidence range from 30-75\% at Main Agricultural 
Research Station at Raichur. In addition, spread of the disease has also been recorded in adjacent areas of Raichur district (Anonymous, 2013), but till date there was no literature available on GPS based distribution and intensity of leaf curl disease incidence of sunflower in potential crop growing areas of Northern Karnataka, spatial and temporal variability of disease have not been studied. Therefor the present study undertaken to investigate spatial and temporal distribution and variability of new leaf curl begomovirus disease on sunflower in Northern Karnataka through global positioning system.

\section{MATERIALS AND METHODS}

A roving survey was conducted to understand spatial and temporal variation of Sunflower Leaf Curl Virus (SuLCV) disease incidence in major sunflower growing areas of Northern Karnataka which included Raichur, Ballari and Koppal districts during Kharif and Rabi 2013 -14. Roving survey was adopted wherein three taluks from each district and two villages from each taluk and two locations of 100 sq meter area were selected as sampling point. Each site was geo referenced in the Universal Transverse Mercator (UTM) co-ordinate system with a Global Positioning System (GPS). By using global positioning system (GPS) (Trimble MAK - Geo XH), where the co-ordinates (latitudes and longitudes) were collected at each sampling point to map the spatial variation of SuLCV disease. Further, the survey was extended to record the incidence of disease in selected points during Rabi 2013-14 to know the temporal variation of disease. The per cent incidence of the viral disease in each location was calculated. Further, the incidence of the disease from each location of the above districts was designated based on disease rating scale $0-3$ (0: No incidence; $1: 1-10 \% ; 2: 11-25 \% ; 3:>25 \%$ and above) for the convenience to develop GIS maps to understand the spatial and temporal variation of disease.

GPS data import: The collected data from each location using GPS were imported using path finder software. Since the projection system of collected locations were pre-defined in the GPS, the imported sample points were found within the respective villages administrative boundary (having similar projection and datum i.e., UTM, WGS 84), when imported in the GIS environment.

Data attachment and mapping: The field observations on leaf curl disease incidence of the respective sampling point were fed in excel sheet with proper labelling for each observations. The unique id was added and the physical id was created along with the sample locations imported in the Arc GIS environment. Further the collected field data were attached to the respective GPS location points using unique id 121 relationships in Arc GIS 2010. The disease incidence was displayed through unique symbology to understand the spatial and temporal variability of leaf curl disease. The Differential Global Positioning System (DGPS) used in this study is the latest version (GeoXH) from Trimble, which is enabled to receive the satellite signals from Global Navigation Satellite System (GNSS) which will give more accurate location reading.

Computer software: ArcGIS 10 software from Department of Plant Pathology, College of Agriculture, Raichur was used for the processing and analysis of the data. During the survey, symptoms of leaf curl disease on sunflower were also observed on different stages of crop growth in order to understandthe susceptible stage of crop.

\section{RESULTS AND DISCUSSION}

The investigations on leaf curl disease of sunflower with respect to GPS based spatial and temporal distribution and variability in major sunflower growing areas of Northern Karnataka were carried out at Department of Plant Pathology and MARS, University of Agricultural Sciences, Raichur. Present study revealed that the leaf curl caused by geminivirus disease found to occur at all the stages of sunflower with characteristic symptoms of vein thickening (enations) on abaxial surface of the leaves, upward curling and reduction in leaf size and severe discoluration of capitulum (Head) followed by stunted growth and poor head formation in many of the locations surveyed (Fig. 1). Similar the infection of gemini viruses found to occur at all the growth stages of crop such as tomato, cassava, tobacco and Okra (Saikia and Muniyappa, 1989, Mathew and Muniyappa, 1991, Valand and Muniyappa, 1992, Venkataravanappa, 2008). However the symptoms caused by these viruses in many vegetable and commercial crops were closely resembles to each other. The GPS based survey of leaf curl disease on sunflower indicated that the per cent incidence of leaf curl disease varied from season to season (temporal variation) across the locations surveyed. During Kharif 2013 the lowest average incidence was observed in many of the locations surveyed with the mean incidence of $11.16 \%, 7.41 \%$ and $6.34 \%$ in Koppal followed by Raichur and Ballari (districts) respectively. Whereas during Rabi/summer 2013-14, higher magnitude of disease incidence noticed in many of the locations surveyed and is ranged from 0.00 to $92.85 \%$. However, Raichur district has recorded highest average incidence $(17.16 \%$ ), while in Koppal and Ballari district, incidences of 16.11 and $7.99 \%$ were recorded respectively.

Further, GPS maps also helps in indicating the spatial variability (Location to location) of leaf curl disease across the surveyed areas and results are represented in GIS maps. Far instances, In Raichur district, during Kharif season maximum disease incidence was noticed to the extent of $46.66 \%$ in University campus of Raichur taluk and while least disease incidence was noticed in Harvi (5.68 \%) village of Manvi taluk. During Rabi season, the incidence recorded in Raichur taluk was $92.85 \%$ and lowest disease incidence was noticed in Venketapur $(5.83 \%)$ village of Lingasugur taluk (Table 1: Fig. 2). In Bellary district, during kharif condi- 
Table 1. Spatial and temporal distribution of leaf curl virus disease incidence on sunflower in Raichur district of North Karnataka during Kharif and Rabi 2013-14.

\begin{tabular}{|c|c|c|c|c|c|c|}
\hline District & Taluk & Location & Longitude & Lattitude & $\begin{array}{c}\text { \% disease inci- } \\
\text { dence during } \\
\text { Kharif }\end{array}$ & $\begin{array}{c}\text { \% disease inci- } \\
\text { dence during } \\
\text { Rabi }\end{array}$ \\
\hline \multirow{14}{*}{ Raichur } & \multirow{6}{*}{ Raichur } & MARS, Raichur & 77.333003 & 16.204984 & 46.66 & 92.85 \\
\hline & & MARS, Raichur & 77.333264 & 16.204869 & 31.11 & 71.42 \\
\hline & & Askihal & 77.325768 & 16.203002 & 0.00 & 7.14 \\
\hline & & Askihal & 77.324835 & 16.204249 & 0.00 & 12.50 \\
\hline & & Eklaspur & 77.291879 & 16.223926 & 0.00 & 0.00 \\
\hline & & Eklaspur & 77.280299 & 16.211488 & 0.00 & 0.00 \\
\hline & \multirow{4}{*}{ Lingsugur } & Maski & 76.656123 & 15.955682 & 5.68 & 17.14 \\
\hline & & Maski & 76.656397 & 15.961840 & 7.14 & 11.57 \\
\hline & & Venketapur & 76.619172 & 15.962151 & 0.00 & 8.33 \\
\hline & & Venketapur & 76.619643 & 15.974040 & 0.00 & 5.83 \\
\hline & \multirow{4}{*}{ Manvi } & Harvi & 77.045010 & 16.070353 & 7.5 & 0.00 \\
\hline & & Harvi & 77.062850 & 16.064410 & 5.71 & 0.00 \\
\hline & & Nirmanvi & 77.099760 & 16.044320 & 0.00 & 0.00 \\
\hline & & Nirmanvi & 77.098250 & 16.045740 & 0.00 & 12.64 \\
\hline
\end{tabular}

Table 2. Spatial and temporal distribution of leaf curl virus disease incidence on sunflower in Ballari district of North Karnataka during Kharif and Rabi 2013-14.

\begin{tabular}{|c|c|c|c|c|c|c|}
\hline District & Taluk & Location & Longitude & Lattitude & $\begin{array}{l}\text { \%o disease inci- } \\
\text { dence during } \\
\text { Kharif }\end{array}$ & $\begin{array}{l}\text { \% disease incidence } \\
\text { during } R a b i\end{array}$ \\
\hline \multirow{14}{*}{ Bellary } & \multirow{5}{*}{ Hadagali } & $\begin{array}{l}\text { Hoovinahada- } \\
\text { gali }\end{array}$ & 75.935426 & 15.016796 & 11.66 & 20.22 \\
\hline & & $\begin{array}{l}\text { Hoovinahada- } \\
\text { gali }\end{array}$ & 75.941539 & 15.017482 & 15.15 & 11.11 \\
\hline & & Uttangi & 76.017286 & 15.003401 & 12.85 & 9.56 \\
\hline & & Uttangi & 76.041785 & 14.974892 & 8.97 & 10.22 \\
\hline & & Kudligi & 76.388834 & 14.902060 & 10.52 & 13.63 \\
\hline & \multirow{5}{*}{ Kudligi } & Kudligi & 76.383819 & 14.901290 & 0.00 & 13.26 \\
\hline & & Kuppinakeri & 76.361220 & 14.913580 & 0.00 & 0.00 \\
\hline & & Kuppinakeri & 76.351360 & 14.888374 & 0.00 & 0.00 \\
\hline & & Gajapur & 76.310928 & 14.874355 & 0.00 & 0.00 \\
\hline & & Gajapur & 76.309179 & 14.873478 & 0.00 & 0.00 \\
\hline & \multirow{4}{*}{$\begin{array}{l}\text { Hagaribomma- } \\
\text { nahalli }\end{array}$} & $\begin{array}{l}\text { Hagari bom- } \\
\text { manahalli }\end{array}$ & 76.199760 & 15.050987 & 10.34 & 14.44 \\
\hline & & $\begin{array}{l}\text { Hagari bom- } \\
\text { manahalli }\end{array}$ & 76.204870 & 15.057544 & 7.69 & 2.98 \\
\hline & & Kadalabalu & 76.218590 & 15.095692 & 0.00 & 16.45 \\
\hline & & Kadalabalu & 76.183250 & 15.098702 & 11.66 & 0.00 \\
\hline
\end{tabular}

Table 3. Spatial and temporal distribution of leaf curl virus disease incidence on sunflower in Koppal district of North Karnataka during Kharif and Rabi 2013-14.

\begin{tabular}{lllcccc}
\hline District & Taluk & Location & Longitude & Lattitude & $\begin{array}{c}\text { \% disease } \\
\text { incidence during } \\
\text { Kharif }\end{array}$ & $\begin{array}{c}\text { \% disease } \\
\text { incidence during } \\
\text { Rabi }\end{array}$ \\
\hline \multirow{6}{*}{ Koppal } & Ginigera & 76.244760 & 15.352285 & 17.85 & 20.20 \\
& & Ginigera & 76.247770 & 15.348448 & 16.88 & 16.92 \\
& & Kanakapur & 76.253540 & 15.342423 & 14.94 & 15.33 \\
& & Kanakapur & 76.266839 & 15.330831 & 9.37 & 22.47 \\
Koppal & Byalihal & 76.137854 & 15.755988 & 12.22 & 15.83 \\
& \multirow{3}{*}{ Kushtagi } & Byalihal & 76.142582 & 15.757263 & 0.00 & 9.23 \\
& & Madalgatti & 76.156504 & 15.738224 & 0.00 & 18.57 \\
& & Madalgatti & 76.162341 & 15.748468 & 15.55 & 21.11 \\
& & Kudri kottagi & 76.041128 & 15.617779 & 7.59 & 13.33 \\
& & Kudri kottagi & 76.038654 & 15.618231 & 0.00 & 12.22 \\
\hline
\end{tabular}

tion, the disease incidence noticed upto $15.2 \%$ from Uttangi village whileduring Rabi, 2013-14 situations the prevalence of disease was highest and recorded upto $20.22 \%$ in Huvinahadagali (Table 2; Fig. 3). 


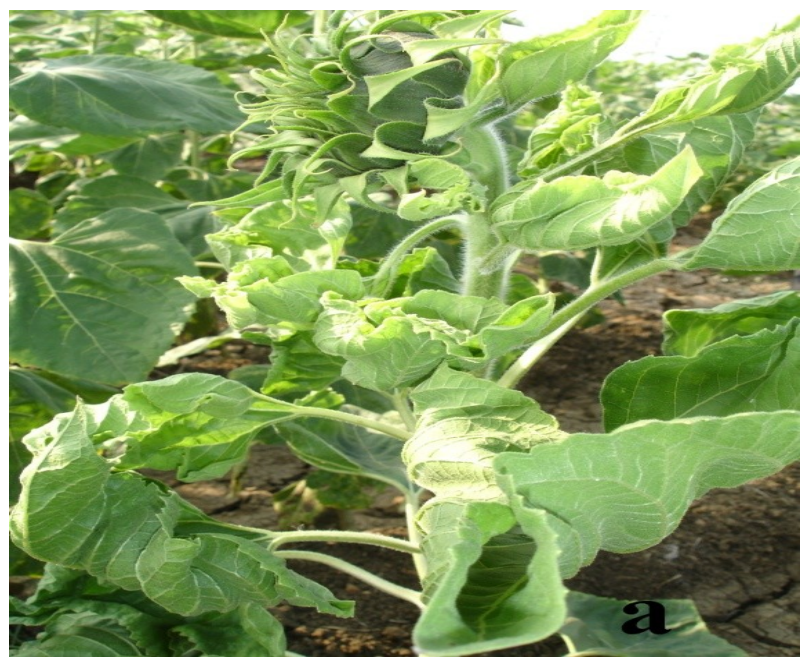

(a) Prominent upward leaf curling

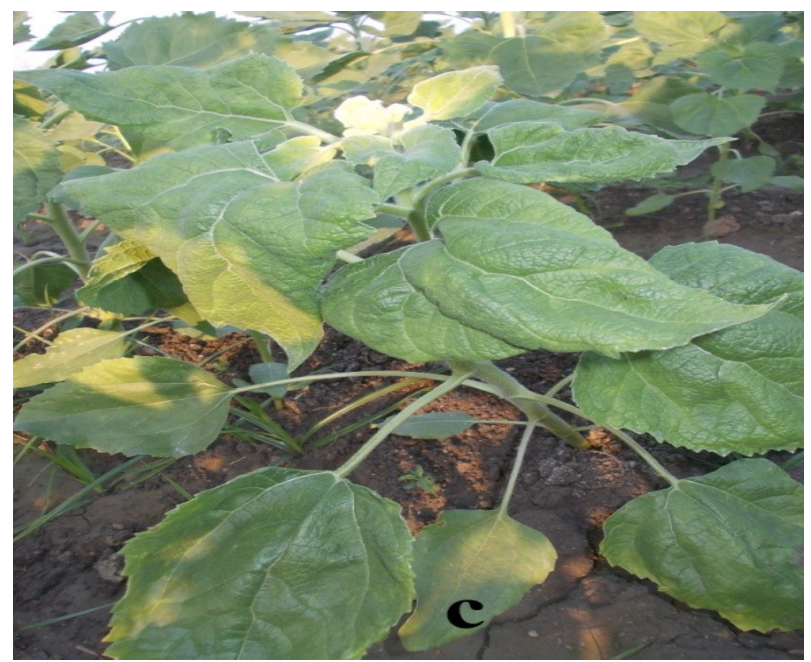

(c) Vein thickenings and leathery Appearance of leaves

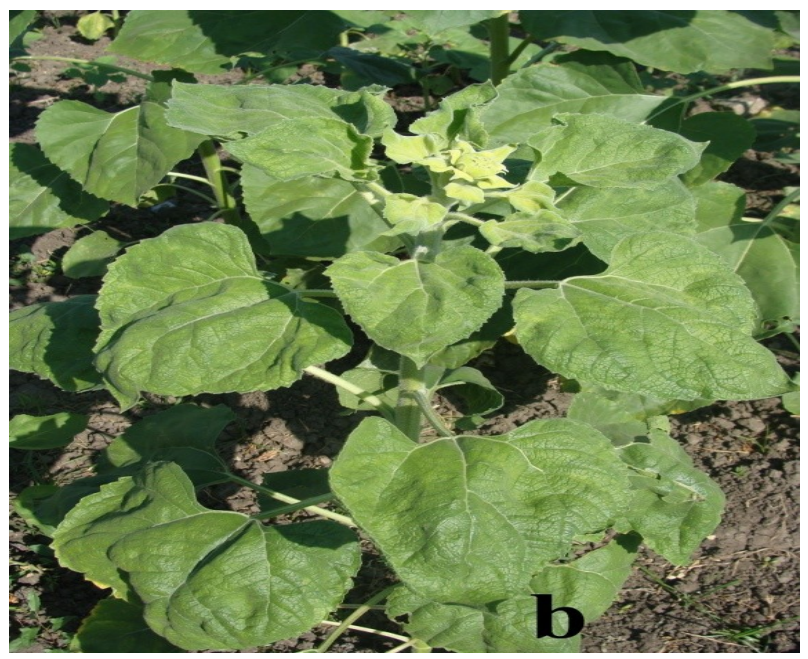

(b) Reduced leaf size and ear head

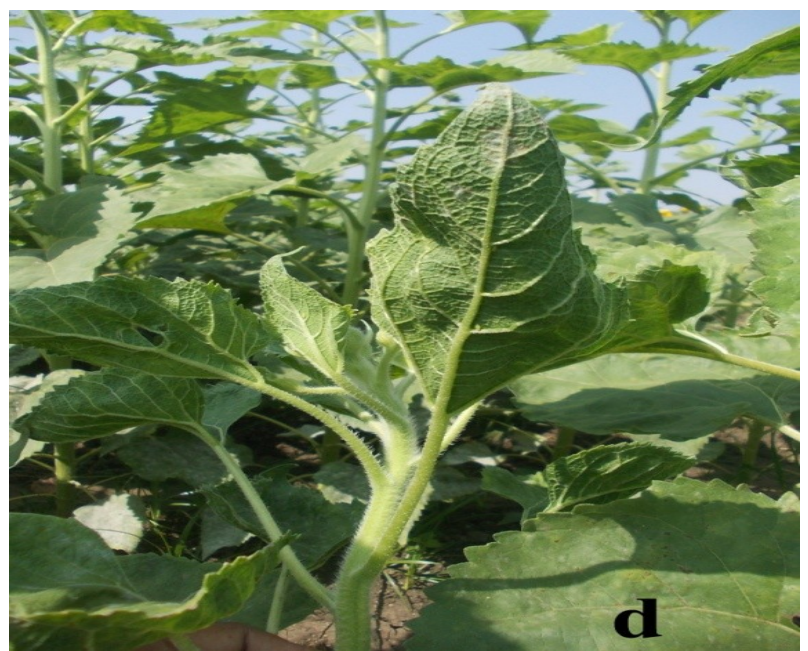

(d) Vein thickening coupled with enations on abaxial surface

Fig. 1. Field symptoms of leaf curl virus disease on sunflower plants.
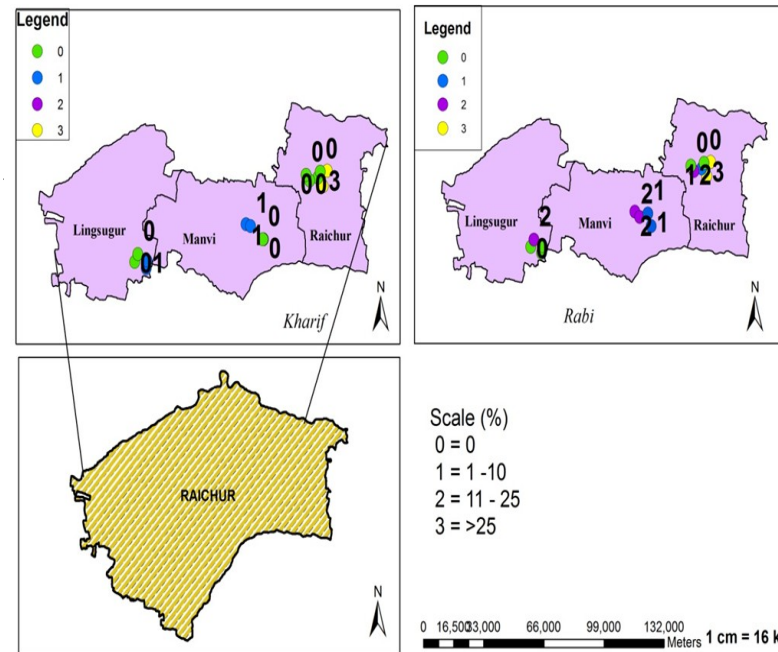

Scale $(\%)$

$0=0$

$1=1-10$

$2=11-25$

$\bigwedge^{N}$

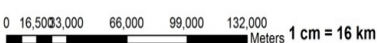

Fig. 2. GIS Map showing spatial and temporal distribution of leaf curl disease during Kharif and Rabi 2013-14 in Raichur district.

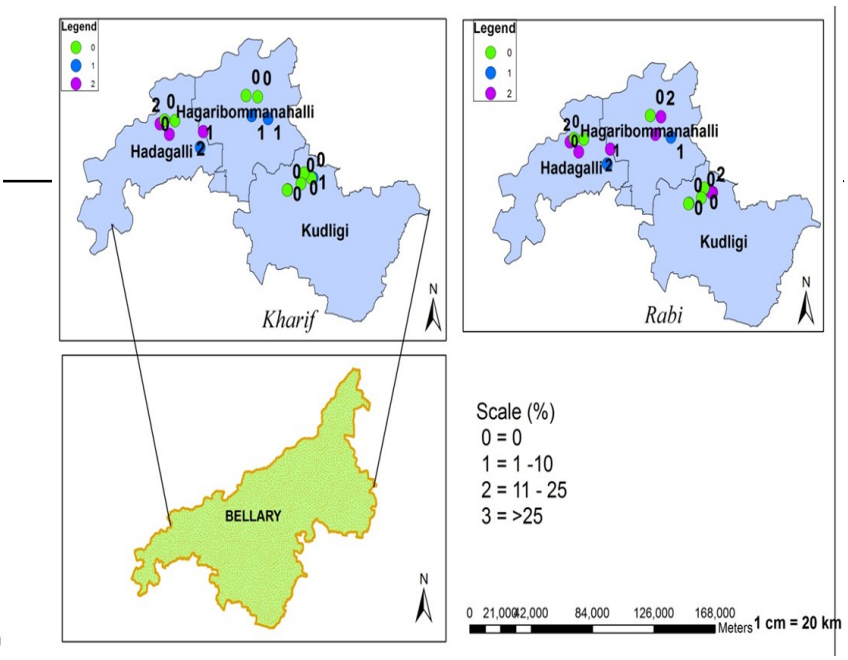

Fig. 3. GIS Map showing spatial and temporal distribution of leaf curl disease during Kharif and Rabi 2013-14 in Ballari district. 


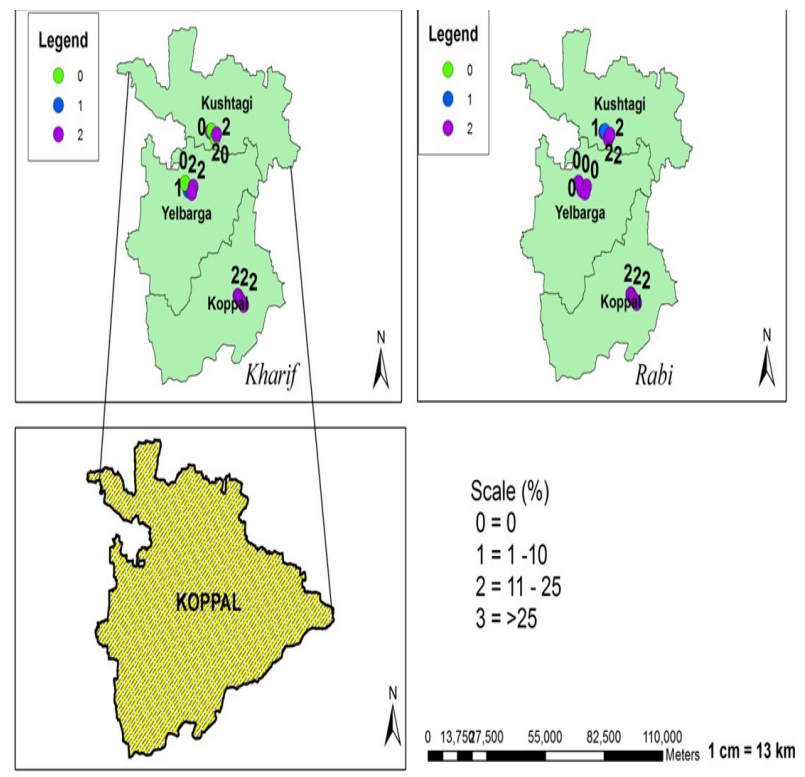

Fig. 4. GIS Map showing spatial and temporal distribution of leaf curl disease during Kharif and Rabi 2013-14 in Koppal district.

In Koppal district, the incidence of leaf curl disease during Kharif reveals that the highest disease incidence $(22.66 \%)$ in Gedigera village of Yelburga taluk and lowest disease incidence was noticed in Kudrikotgi (7.59 \%) village of Yelburga taluk. Whereas during Rabi 2013 -14 the disease incidence was highest $(22.47 \%)$ in Kanakapur village of Koppal taluk and lowest disease incidence was noticed in Byalihal $(9.23 \%)$ village of Kushtagi taluk (Table 3; Fig. 4).

The survey on leaf curl disease across sunflower growing regions of North East Karnataka revealed that the \% disease incidence varied from location to location and also from season to season, which indicates the leaf curl disease is highly sporadic and varying across the locations.

The differences in the incidence of disease in areas surveyed might be due to the variation in the source of virus inoculum (ToLCV Karnataka clone IKH12) (Vanitha, 2012), vector population, climatic conditions and the susceptibility of sunflower genotypes. Interestingly, in the areas where maximum disease incidence was recorded, the vector population was apparently high with a favourable temperature conditions during Rabi/summer periods. B. tabaci is readily capable of establishing to extreme population levels with higher temperature, particularly crops grown under irrigated and arid field conditions and greenhouse systems. In addition to this, whitefly has the potential to colonize a wide range of dicotyledonous species, among which are primarily vegetable and fiber species. Recent studies indicated that there are numerous populations of $B$. tabaci that, vary in their capacity to develop high population densities and cause direct feeding damage, in the extent of their host ranges, and in the efficacy with which they can transmit geminiviruses (Bedford et al., 1994). Some of them are also known to be source of infections for other Begomoviruses. In addition introduction of B-biotype whitefly has been attributed for epidemics and emergence of new viruses in Southern parts of Karnataka (Banks et al., 2001). In recent years there have been wide spread occurrence of Begomoviruses on many crop plants as well as ornamental plant species Hibiscus (Rajeshwari et al., 2005), Zinnia (Shivakumar, 2010) and Croton (Mahesh et al., 2010). Further investigations on cotton leaf curl virus (CLCuV) incidence in North India, also coincided with variation in virus strains across the locations. Until 2004, CLCuRV (Rajasthan strain) was predominant in North West India but during 2005- 06, $\mathrm{CLCuBuV}$ (Burewala strain) appeared to be a new Begomovirus and in the recent years of 2009-10 onwards $\mathrm{CLCuBuV}$ emerged as dominant resistance breaking strain in NW India. A survey for viruses causing CLCuD was conducted by Rajagopalan et al. (2012) during the 2009 and 2010 cropping seasons in the northwestern Indian cotton-growing belt in the states of Punjab, Haryana and Rajasthan. Partial sequences of 258 and full-length sequences of 22 virus genomes were determined. This study showed that the resistancebreaking cotton leaf curl Burewala virus $(\mathrm{CLCuBuV})$ is now the dominant virus in many fields. Hence further detail investigations is need of an hour to understand the diversity pattern of leaf curl strain infecting sunflower in Karnataka.

The maps showed that a different colour in legends represents high and low risk areas of the disease with $\%$ disease incidence and based on severity scale (0-3). This result shows the various steps to move from overall scenario of disease to pin pointing the disease incidence in a location specific or hotspot analysis. The variability of associations is likely due to the fact that various environmental factors and biotic factors such as sources of disease inoculum, temperature, rainfall, relative humidity, host susceptibility, etc., and their spatial heterogeneity affect the incidence and epidemic development of viral disease.

Govindappa et al. (2011) reported leaf curl virus disease on sunflower to the extent of $40 \%$ at Main Agricultural Research Station, University of Agricultural Sciences, Raichur. Further, Vanitha (2012) made a survey in five districts of northern and southern Karnataka and the studies revealed that the incidence in sunflower ranged from $0-58 \%$ and highest incidence of $58 \%$ was recorded at Main Agriculture Research Station, University of Agricultural Sciences, Raichur, However there was no incidence in Tumkur and Bengaluru rural district. Further Deepa (2013) conducted a survey in five districts of northern Karnataka and during the study the mean disease incidence of $11.68 \%$ in Raichur district followed by Koppal (7.59 \%), and Yadgiri (3.22 \%). From the above studies, it is clear that Raichur recorded highest incidence among the districts surveyed and it is occurring repeatedly in Raichur locations hence, 
Raichur can be one of the "hot spot" for leaf curl virus incidence which recorded 57.9 and $65.25 \%$ disease incidence in Kharif 2012 and Rabi/summer 2012-2013, respectively. Further, the present investigation also reveals that the incidence of leaf curl disease on sunflower at MARS, Raichur is highest of 46.66 and 92.85 \% during Kharif 2013 and Rabi/summer 2013-14, respectively.

\section{Conclusion}

Present investigations on Leaf curl disease of sunflower caused by begomovirus revealed that the disease was found to occur at all the stages of sunflower under field condition across the locations surveyed. GPS based survey indicated that the \% disease incidence varied from location to location (spatial variation) and also from season to season (temporal variation). The low incidence was noticed during Kharif condition Whereas during Rabi/summer season, high magnitude of disease noticed in many of the locations surveyed and is recorded upto $92.9 \%$. The GPS maps plotted based on PDI scale (0-3) represents high risk areas of the disease in Raichur and adjacent areas of North Eastern Karnataka and the result further shows that the disease occurrence was more in rabi as compared to Kharif situations irrespective of locations.

\section{ACKNOWLEDGEMENTS}

This research is part of M.Sc (Agri.) dissertation and authors are very much thankful to Ex. ViceChancellor, UAS, Raichur, Dr. B.V. Patil for providing financial grants through Demand driven project and also for his moral support in fulfilling the basic research of this programme.

\section{REFERENCES}

Anonymous, 2013, Annual Sunflower report, 2013, Directorate of Oilseed Research, Hyderbad, 254.

Banks, G.K., Colvin, J., Chowda Reddy, R.V., Maruthi, M. N., Muniyappa, V., Venkatesh, H.M., Kiran Kumar, M., Padmaja, A.S., Beitia, F.J. and Seal, S.E. (2001). First report of the Bemisia tabaci B-biotype in India and an associated Tomato leaf curl virus disease epidemic. Plant Disease, 85: 231.

Bedford, I.D., Briddon, R.W., Jones, P., Alkaff, N. and Markham, P.G. (1994). Differentiation of three whitefly transmitted geminiviruses from the Republic of Yemen. European J. Pl. Pathol., 100: 243-257.

Brown, J.K. (1994). Current status of Bemisia tabaci as a plant pest and virus vector in agro-ecosystems worldwide. FAO Plant Prot. Bull., 42: 3-32.

Govindappa, M.R., Shankergoud, I., Shankarappa, K.S., Wickramaarachchi, W.A.R.T., Anjeneya Reddy, B. and Rangaswamy, K.T. (2011). Molecular detection and partial characterization of begomovirus associated with leaf curl disease of sunflower (Helianthus annuus) in Southren India. Plant Pathol. J., 10 (1): 29-35.

Joshi, D.B. (2009). Developing Statistical Models to Study the Growth and Instability in Oilseed Production of Karnataka. Unpublished thesis of Master of Science
(Agriculture) in Agricultural Statistics, submitted to the University of Agricultural Sciences, Dharwad, Karnataka (India).

Kaur S.I., 1 Kang, S.S and Sharma, A. (2015). Occurrence of begomoviruses in cotton-vegetable agro ecosystem in India, African Journal of Microbiology Research., 9 (30), 1798-1805.

Mahesh, Y.S., Shankarappa, K.S., Rangaswamy, K.T., Prameela, H.A., Aswathanarayana, D.S., Divya, B.L., Nagesha, N., and Maruthi, M.N. (2010). Detection and characterization of a Begomovirus associated with leaf curl disease of ornamental croton (Codiaeum variegatum). J. Hort. Sci. Biotech., 85: 101-105.

Mathew, A.V. and Muniyappa, V. (1991). Transmission of Indian cassava mosaic virus by Bemisia tabaci. Fitopatologia Brasileira, 16: 46-49.

Mündel, H.H. (2009). Sunflowers: An Important Part of the Tool kit for Dry-land Farming. Australian Grain, January-February 2009:30-33.

Muniyappa, V. and Veeresh, G.K. (1984). Plant virus diseases transmitted by whiteflies in Karnataka. Indian Acad. Sci. (Anim. Sci.), 93: 397-406.

Rajagopalan, P.A., Naik, A., Katturi., P. and Kurulekar, M. (2012). Dominance of resistance breaking cotton leaf curl Burewala virus $(\mathrm{CLCuBuV})$ in north western India. Arch. Virol., 157:855-868.

Rajeshwari, R., Reddy, R.V.C., Maruthi, M.N., Colvin, J., Seal, S.E. and Muniyappa, V. ( 2005). Host range, vector relationships and sequence comparison of a begomovirus infecting hibiscus in India. Ann. Appl. Biol., 147: 15-25.

Ramappa, H.K., Muniyappa, V and Colvin, J. (1998). The contribution of tomato and alternative host plants to tomato leaf curl virus inoculums pressure in different areas of south India. Annals of Applied Biology, 88: 369 $-387$.

Saharan, G.S., Naresh Mehta and Sangwan, M. S. (2005). Diseases of Oil Seed Crops, ISBN-81-7387-176-0, Indus publishing company, New Delhi, pp.38.

Saikia, A.K., and Muniyappa, V. (1989). Epidemiology and control of tomato leaf curl virus in southern India. Trop. Agri., 66: 350-354.

Shivakumar (2010). Studies on Zinnia leaf curl virus disease, M.Sc. (Agri.) Thesis., Univ. Agri. Sci., Bangalore, India, $78 \mathrm{pp}$.

Shivalingam, P.N., Padmalatha. K.V., Mandal. B., Monga. D., Ajemra, B.D and Malathi VG (2007). Detection of begomoviruses by PCR in weeds and crop plants in and around cotton field infected with cotton leaf curl disease. Indian Phytopathol, 60: 360-361.

Valand, G.B. and Muniyappa, V. (1992). Epidemiology of tobacco leaf curl virus in India. Ann. Appl. Biol., 120: 257-267.

Vanitha, L.S. (2012). Molecular characterization of begomovirus causing leaf curl disease in sunflower. Ph.D Thesis, Univ. Agri. Sci., Bangalore.

Varma, A. and Malathi, V.G. (2003). Emerging geminivirus problems: A serious threat to crop production. Ann. Appl. Biol. 142: 145-164.

Venkataravanappa (2008). Molecular characterization of bhendi yellow vein mosaic virus. Ph.D Thesis, Univ. Agri. Sci., Bangalore.

Zhang, N., Wang, M. and Wang, N. (2002). Precision agriculture - a worldwide overview. Computers and Electronics in Agriculture, 36: 113-132. 